University of Nebraska - Lincoln

DigitalCommons@University of Nebraska - Lincoln

\title{
Multiscale Habitat Use and Selection in Cooperatively Breeding Micronesian Kingfishers
}

Dylan C. Kesler

U.S. Geological Survey

Susan M. Haig

U.S. Geological Survey, Susan_Haig@usgs.gov

Follow this and additional works at: https://digitalcommons.unl.edu/usgsstaffpub

Kesler, Dylan C. and Haig, Susan M., "Multiscale Habitat Use and Selection in Cooperatively Breeding Micronesian Kingfishers" (2007). USGS Staff -- Published Research. 684.

https://digitalcommons.unl.edu/usgsstaffpub/684

This Article is brought to you for free and open access by the US Geological Survey at DigitalCommons@University of Nebraska - Lincoln. It has been accepted for inclusion in USGS Staff -- Published Research by an authorized administrator of DigitalCommons@University of Nebraska - Lincoln. 


\title{
Multiscale Habitat Use and Selection in Cooperatively Breeding Micronesian Kingfishers
}

\author{
DYLAN C. KESLER, ${ }^{1,2}$ United States Geological Survey, Forest and Rangeland Ecosystem Science Center, 3200 S.W. Jefferson Way, Corvallis, OR 97331, \\ USA, and Department of Fish and Wildlife, Oregon State University, Corvallis, OR 97331, USA \\ SUSAN M. HAIG, United States Geological Survey, Forest and Rangeland Ecosystem Science Center, 3200 S.W. Jefferson Way, Corvallis, OR 97331 , USA
}

\begin{abstract}
Information about the interaction between behavior and landscape resources is key to directing conservation management for endangered species. We studied multi-scale occurrence, habitat use, and selection in a cooperatively breeding population of Micronesian kingfishers (Todiramphus cinnamominus) on the island of Pohnpei, Federated States of Micronesia. At the landscape level, point-transect surveys resulted in kingfisher detection frequencies that were higher than those reported in 1994, although they remained $15-40 \%$ lower than 1983 indices. Integration of spatially explicit vegetation information with survey results indicated that kingfisher detections were positively associated with the amount of wet forest and grass-urban vegetative cover, and they were negatively associated with agricultural forest, secondary vegetation, and upland forest cover types. We used radiotelemetry and remote sensing to evaluate habitat use by individual kingfishers at the home-range scale. A comparison of habitats in Micronesian kingfisher home ranges with those in randomly placed polygons illustrated that birds used more forested areas than were randomly available in the immediate surrounding area. Further, members of cooperatively breeding groups included more forest in their home ranges than birds in pair-breeding territories, and forested portions of study areas appeared to be saturated with territories. Together, these results suggested that forest habitats were limited for Micronesian kingfishers. Thus, protecting and managing forests is important for the restoration of Micronesian kingfishers to the island of Guam (United States Territory), where they are currently extirpated, as well as to maintaining kingfisher populations on the islands of Pohnpei and Palau. Results further indicated that limited forest resources may restrict dispersal opportunities and, therefore, play a role in delayed dispersal and cooperative behaviors in Micronesian kingfishers. (JOURNAL OF WILDLIFE MANAGEMENT 71(3):765-772; 2007)
\end{abstract}

DOI: $10.2193 / 2006-011$

KEY WORDS cooperative breeding, Halcyon cinnamomina, island conservation, Micronesia, Micronesian kingfisher, movement, Pohnpei, Todiramphus cinnamominus.

The 3 subspecies of Micronesian kingfishers from the islands of Guam (United States Territory; Todiramphus cinnamominus cinnamominus), Pohnpei (Federated States of Micronesia; T. c. reichenbacbii), and Palau (Republic of Palau; T. c. pelewensis) face dire conservation situations. The Guam Micronesian kingfisher is among the most endangered species in the world, as it is extinct in its native range (Haig and Ballou 1995) and now exists only as a captive population of $<100$ birds (B. Bahner, Philadelphia Zoo, personal communication). The wild population of Micronesian kingfishers on Pohnpei has declined by as much as $63 \%$ over the last 2 decades (Buden 2000), and survey results have not been reported from Palau in $>15$ years (Engbring 1992).

Despite their endangered conservation status, previous research has addressed only the most basic aspects of Micronesian kingfisher natural history. Publications include mostly anecdotal descriptions (Stophlet 1946, Marshall 1949, Baker 1951, Jenkins 1983, Fry et al. 1992) and information for captive breeding institutions (Haig et al. 1995, Baltz 1998, Kesler and Haig 2004, Sanchez and Murray 2005). Additionally, investigators have assessed demography (Kesler 2006), nest-site selection (Marshall 1989; Kesler 2002; Kesler and Haig 2005a, b, 2007a), and movement (Kesler and Haig 2007b). Population estimates

${ }^{1}$ E-mail: DylanKesler@picra.net

${ }^{2}$ Present address: Biological Sciences Department, 4095 Derring Hall, Virginia Polytechnic Institute and State University, Blacksburg, VA 24061, USA
(Engbring and Ramsey 1984, Engbring 1992, Engbring et al. 1990, Buden 2000) show that Micronesian kingfisher densities vary among vegetation types on the islands they inhabit, which suggests that habitat features may provide differential utility for the birds. However, additional information about habitat selection and use is lacking, despite its vital importance to agencies managing declining wild populations and those working to reintroduce Guam Micronesian kingfishers to their native range (United States Fish and Wildlife Service 2004).

In Pohnpei Micronesian kingfishers, some individuals disperse and attempt to reproduce independently, whereas others delay dispersal and assist parents with future reproduction (Kesler 2002; Kesler and Haig 2005b, 2007b). This behavior, known as cooperative breeding, has the potential to influence population dynamics by effectively removing helper adults from the breeding population (e.g., Heppell et al. 1994); hence, it can also affect progress toward recovery of endangered populations. Limited habitat resources have previously been invoked as the underlying cause of delayed dispersal and cooperation in some species, when ecological constraints prevented dispersal (Emlen 1982) or when high-quality resources on natal territories encouraged a delay in potential dispersers (Stacey and Ligon 1991; for review see Brown 1987, Koenig and Dickinson 2004). Therefore, identifying limited resources can profoundly influence both our understanding of cooperative behaviors and the conservation management of endangered species. For example, identification of resource limitations in endangered red-cockaded woodpeckers (Picoides borealis) 


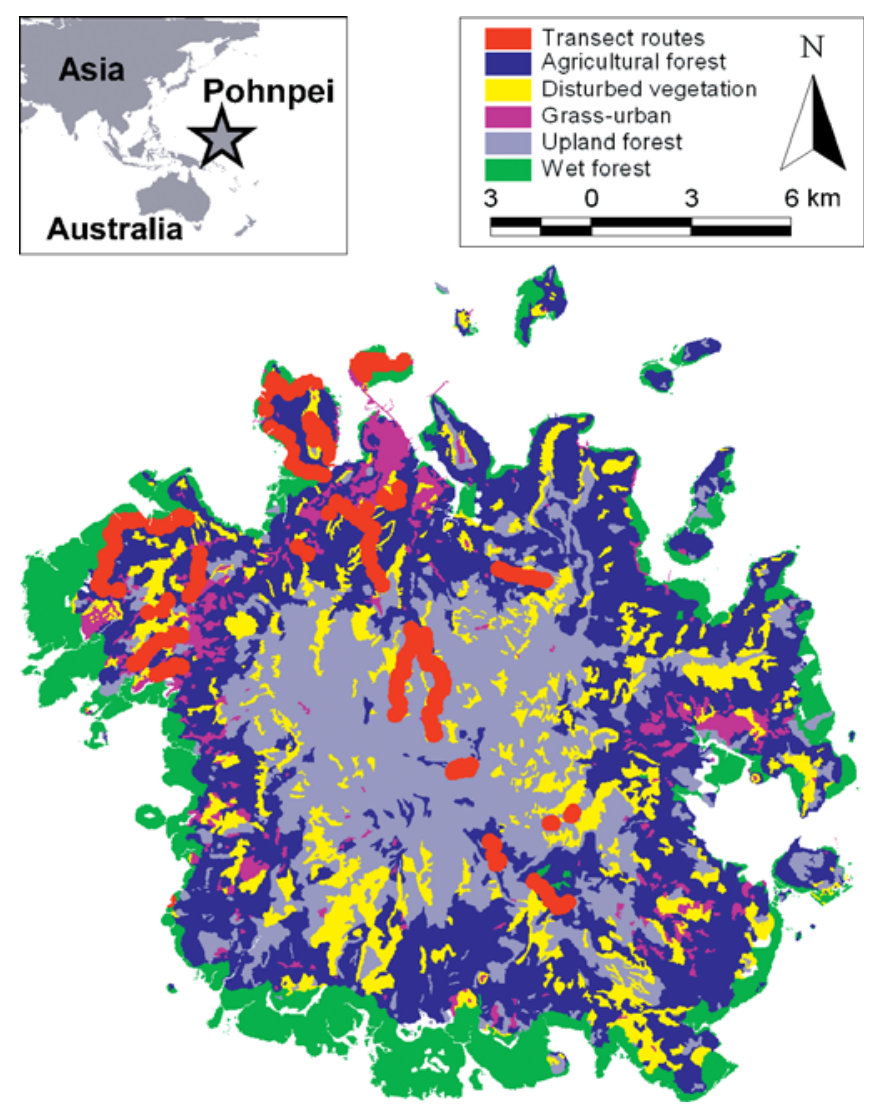

Figure 1. Map of point-transect locations and vegetation cover types on the island of Pohnpei, Federated States of Micronesia, where we studied Micronesian kingfishers from 1999 to 2005.

and Sechelles warblers (Acrocephalus sechellensis) was important to preventing the extinction of these species (Copeyon et al. 1991, Conner et al. 2001, Komdeur and Pels 2005), and it simultaneously led to fundamental insights into the evolution of cooperative behaviors (Komdeur 1991, 1992, 1994; Walters et al. 1992). Despite the close theoretical tie between resources and cooperative social behaviors, however, only a few have attempted empirical evaluations of resources used by cooperative breeders (Clarke and FitzGerald 1994, Langen and Vehrencamp 1998, Hale et al. 2003, Carmen 2004).

We studied Micronesian kingfisher occurrence, habitat use, and selection at the second- and third-order scales (Johnson 1980). At the landscape scale we assessed the relationship between kingfisher occurrence and habitat throughout the island of Pohnpei, and at the home-range scale we evaluated habitat use and selection. We identified habitats with resources important for reproduction and results provided insight into the resource requirements of birds in each of 3 social classes (juv, delayed dispersers, and dominants). Further, we identified limited resources with the potential to restrict dispersal opportunities in Micronesian kingfishers.

\section{STUDY AREA}

We conducted research on the island of Pohnpei $\left(6^{\circ} 52^{\prime} \mathrm{N}\right.$, $158^{\circ} 13^{\prime} \mathrm{E}$; Fig. 1). Pohnpei is a circular island with an approximate diameter of $20 \mathrm{~km}$ circumscribing the highest peak in the Micronesian chain (nearly $800 \mathrm{~m}$; Engbring et al. 1990). Extensive lowland coastal plateau and mangrove swamps surrounded the inner mountain range, which was characterized by dense tropical rainforests. We conducted transect surveys throughout the island and in all elevation zones. Telemetry work occurred primarily at 3 locations, the Ranch $\left(6^{\circ} 57^{\prime} \mathrm{N}, 158^{\circ} 12^{\prime} \mathrm{E}\right)$, College of Micronesia $\left(6^{\circ} 54^{\prime} \mathrm{N}\right.$, $\left.158^{\circ} 9^{\prime} \mathrm{E}\right)$, and Palikir $\left(6^{\circ} 55^{\prime} \mathrm{N}, 158^{\circ} 9^{\prime} \mathrm{E}\right)$ study areas. These areas included strand vegetation, early succession and mature lowland rainforest, grassland, urban vegetation, and agroforest. Grassy areas included pastures and fallow fields. Early succession and agricultural forest vegetation were characterized by lower canopy $(2-20 \mathrm{~m})$ hibiscus (Hibiscus tiliaceus), banana (Musa sapientum), coconut (Cocos nucifera), breadfruit (Artocarpus altilis), and sakau (Piper methysticum). Mature forests had a higher canopy $(25-30 \mathrm{~m})$ and were dominated by mango (Mangifera indica), dohng (Campnosperma brevipetiolata), sadak (Elacocarpus carolinensis), karara (Myristica insularis), ais (Parinari laurina), and tree ferns (Cyathea spp.; Mueller-Dombois and Fosberg 1998, Buden 2000). Additional characteristics of the island and study sites are addressed below and they have been described elsewhere (McClean et al. 1998; Buden 2000; Kesler 2002, 2006).

\section{METHODS}

\section{Landscape Scale}

We used point-transect surveys in combination with vegetation coverage information to model the relationship between Micronesian kingfisher occurrence and landscape features. During the 2000 breeding season for Pohnpei Micronesian kingfishers (Apr and May), observers traversed 20 transect routes and conducted 184 point-transect surveys (Buckland et al. 1993). Transects were distributed throughout the island and occurred at all elevations (Fig. 1). Along each route, we conducted surveys at stations separated by $>200 \mathrm{~m}$, which we determined using Global Positioning Systems (GPS). At each station, observers recorded visual observations and calls of Micronesian kingfishers during 10minute periods between 0600 hours and 1000 hours. Micronesian kingfishers rarely move off home territories (Kesler and Haig 2007b), so detections made during transect surveys likely reflected resident individuals and provided an index of local population densities.

Previously published habitat maps indicated that 16 vegetation classifications occurred within transect areas, including agroforestry, forest with invasive Albizia sp., barren, cropland, coconut forest, dwarf forest, grassland, freshwater marsh, mangrove forest, saltwater marsh, ivorynut palm (Phytelephas macrocarpa) forest, palm forest, secondary vegetation, swamp forest, urban vegetation, and upland forest (Newsome et al. 2003). We aggregated vegetation polygons into 5 coverage classifications based on vegetative structure, which included 1) agricultural forest (agroforestry, cropland, coconut forest, and palm forest), 2) disturbed vegetation (secondary vegetation and forest with 
Albizia sp.), 3) wet forest (mangrove forest, saltwater marsh, freshwater marsh, and swamp forest), 4) upland forest (dwarf forest, ivory-nut palm forest, upland forest), and 5) grass-urban (barren, grassland, and urban vegetation).

We used a Geographic Information System (GIS; ArcView 2002, XTools 2003) to evaluate the amount of area comprised of each vegetation cover type within $250 \mathrm{~m}$ of point-transect stations. We then compared vegetative cover at point-transect stations where we detected Micronesian kingfishers to cover at stations where we did not detect birds using 2-sample $t$-tests. Additionally, we modeled the relationship between vegetation and kingfisher detections by regressing the number of birds detected at each pointtransect station against the amount of vegetation in each cover class within $250 \mathrm{~m}$. We fitted all additive linear combinations of the 5 vegetation variables to survey responses using Poisson regression (SAS Version 8e; SAS Institute, Cary, NC). We ranked models using second-order Akaike's Information Criterion $\left(\mathrm{AIC}_{c}\right.$; Burnham and Anderson 2002) and derived model-averaged parameter estimates for models comprising the top $90 \%$ of $\mathrm{AIC}_{c}$ weight $\left(w_{i}\right)$.

\section{Home-Range Scale}

Study population.-We radiomarked and color-banded a population of Micronesian kingfishers on the 3 study areas between January 1999 and January 2004. We captured birds in mist nets, marked them with unique combinations of colored leg bands, and fitted them with 1.8-g telemetry packages (Holohil Systems, Ltd., Ottawa, ON, Canada) using the leg-harness design of Rappole and Tipton (1991). We determined the age and sex of each bird using molecular analyses and morphological characteristics (Kesler et al. 2006). We then observed radiomarked birds from January to July 1999, March to September 2000, and September 2002 to January 2003. We believe that we knew the social class of all individuals because observers were present on study areas daily. Hereafter, we follow the terminology of recent literature (e.g., Haydock and Koenig 2002): dominant refers to putative breeders on a territory, helper refers to offspring that have delayed dispersal through subsequent parental reproductive attempts, and juvenile describes progeny from the most recent breeding season.

Radiotelemetry and home range.-We used radiotelemetry and GIS analyses to assess the home-range characteristics of Micronesian kingfishers. During each telemetry session, we used hand-held Yagi antennas, compasses, and GPS (March III, Corvallis Microtechnologies) to record bearing groups of 2-5 directional bearings for each Micronesian kingfisher. Using the default settings in LOAS (LOAS Version 4.0b; Ecological Software Sollutions, Urnäsch, Switzerland), we estimated the best maximum likelihood locations for bearing groups. We excluded bearing groups if LOAS failed to identify a location, or if locations had $95 \%$ error ellipses $>5,000 \mathrm{~m}^{2}$, which represents approximately $10 \%$ of the area of a mean Micronesian kingfisher home range (Kesler and Haig 2007b). We recorded the actual location of birds that were visually observed using the offset function of the GPS. We located birds daily and all observations were separated by $\geq 2$ hours to avoid autocorrelation. With the exception of several sessions cut short by factors unrelated to bird movement (e.g., weather and equipment failure), we further avoided biasing results (Porter and Dooley 1993; Koenig et al. 1996, 2000) by locating birds every time we attempted to find them. Previous work indicated that birds do not make substantial nocturnal movements between sunset and sunrise (Kesler and Haig 2007b), so we balanced sampling equally during 2-hour time blocks between 0600 hours and 1800 hours. We eliminated locations that were within $15 \mathrm{~m}$ of nest sites because kernel density analyses can be biased by nest-associated clusters of locations during the breeding season (White and Garrott 1990). Micronesian kingfishers occasionally depart from home areas on extraterritorial forays and the resulting disparate point distributions can substantially enlarge home-range estimates. Thus, we eliminated 170 locations that met previously described prospecting criteria (Kesler and Haig 2007b), including locations that were $>50 \mathrm{~m}$ outside territorial boundaries and surrounded by a single-kernel polygon island. The process yielded 3,721 locations from which to derive 61 Micronesian kingfisher home ranges.

Habitat availability and use.-We assessed habitats available to Micronesian kingfishers on each of the 3 study areas using vegetation cover maps that have been described elsewhere (Kesler 2002, Kesler and Haig 2005b). In general, we used high-resolution ( $1 \mathrm{~m} /$ pixel) visual-spectrum aerial photographs to conduct an unsupervised habitat classification that divided the visual spectrum of each photograph into 10 signatures with a clustering algorithm (Avery and Berlin 1992). We manually combined signatures in a supervised classification (Avery and Berlin 1992), which incorporated information about areas of known vegetation types. The process resulted in 4 habitat coverages depicting sparse and short grassy vegetation, long grasses and brush, early succession and agricultural forest vegetation, and mature forest vegetation (species compositions are described above). We verified habitat classifications with comparisons to aerial photographs and vegetation coordinate information recorded with a GPS during fieldwork.

We selected 5 biologically relevant metrics to represent habitats used by breeding Micronesian kingfishers within their home ranges. Four metrics came directly from remotesensing analyses as the kingfishers used short-grass and tallgrass areas for foraging, early succession forest for foraging and loafing, and late-succession forests for loafing and nesting (Kesler 2002, Kesler and Haig 2005b). Additionally, we evaluated the length of forest edge because the birds often forage near edges. We constructed spatially referenced GIS coverages of each habitat metric and we derived estimates for each home range. We log-transformed habitat values and used mixed-models analysis of variance (Proc Mix; SAS Institute) to compare mean habitat areas among social classes. Models included random effects variables for territory and fixed effects variables for social classes. We also 
Table 1. Results of model selection analysis relating the number of Micronesian kingfishers detected during point-transects with vegetation cover within 250 $\mathrm{m}$ of point-transect stations on the island of Pohnpei, Federated States of Micronesia, 2000. We present the 12 top-ranked models.

\begin{tabular}{|c|c|c|c|c|c|}
\hline Rank & Model $^{\mathbf{a}}$ & $k$ & $\mathrm{AIC}_{c}^{\mathrm{b}}$ & $w_{i}^{\mathbf{c}}$ & Sum $w_{i}$ \\
\hline 1 & ag. forest + disturbed veg. + upland forest & 4 & $1,039.6$ & 0.18 & 0.18 \\
\hline 2 & ag. forest + wet forest + upland forest + grass-urban & 5 & $1,040.1$ & 0.14 & 0.31 \\
\hline 3 & ag. forest + disturbed veg. + upland forest + grass - urban & 5 & $1,040.7$ & 0.10 & 0.42 \\
\hline 4 & ag. forest + upland forest + grass-urban & 4 & $1,041.2$ & 0.08 & 0.50 \\
\hline 5 & disturbed veg. + wet forest + grass-urban & 4 & $1,041.2$ & 0.08 & 0.58 \\
\hline 6 & ag. forest + wet forest & 3 & $1,041.5$ & 0.07 & 0.64 \\
\hline 7 & ag. forest + disturbed veg. + wet forest + upland forest & 5 & $1,041.6$ & 0.06 & 0.71 \\
\hline 8 & disturbed veg. + wet forest + upland forest + grass-urban & 5 & $1,041.8$ & 0.06 & 0.77 \\
\hline 9 & ag. forest + disturbed veg. + wet forest + upland forest + grass-urban & 6 & $1,042.2$ & 0.05 & 0.82 \\
\hline 10 & ag. forest + upland forest & 3 & $1,042.4$ & 0.04 & 0.86 \\
\hline 11 & ag. forest + disturbed veg. + wet forest + grass-urban & 5 & $1,042.7$ & 0.04 & 0.90 \\
\hline 12 & wet forest + upland forest + grass-urban & 4 & $1,042.9$ & 0.03 & 0.93 \\
\hline
\end{tabular}

${ }^{a}$ Models included variables for agricultural forest (ag. forest), secondary vegetation and forest with invasive Albizia sp. (disturbed veg.), upland forest, marsh and mangrove forests (wet forest), and grass-urban habitats.

b Akaike's Information Criterion.

c Akaike wt.

employed a mixed-models approach to compare males and females. We used linear models (Proc GLM; SAS Institute) to compare habitats in the home ranges of breeders and juveniles on cooperative and pair-held territories. To account for the influence of multiple comparisons, we adjusted least-squared means estimates with the Bonferroni method (Ramsey and Schafer 1997).

We compared vegetative coverage in each kingfisher home range with vegetation in 8 randomly placed polygons of similar size and shape to determine whether Micronesian kingfishers selected or avoided particular vegetation types (Katnik and Wielgus 2005). We hypothesized that if Micronesian kingfishers were selecting particular habitat features, then coverage distributions in observed home ranges would differ from those in randomly placed polygons. Observed home ranges were defined by the $95 \%$ use contour from kernel-density analyses and simulated polygons included 8 polygons matching the size and shape of each observed home range. We shifted simulated polygons away from observed home-range locations in 8 random directions and at random distances between $100 \mathrm{~m}$ and 200 $\mathrm{m}$. We tested whether birds were using habitats differently from what was randomly available in the immediately surrounding area by retaining simulated polygons within the general vicinity of the observed home range. Within home ranges and simulated polygons, the areas comprised of each of the 4 vegetation types, and the length of forest edge was calculated using the GIS. We then compared used and available habitat proportions in home ranges and simulated polygons with the method of Neu et al. (1974) and the software package Resource Selection for Windows (Leban 1999). We also made Bonferroni adjustments to confidence intervals to account for multiple comparisons (Ramsey and Schafer 1997). Statistical tests used for each analysis, 95\% confidence intervals, and least-squared mean parameter estimates are presented whenever appropriate. Unless otherwise noted, estimates are reported as means with standard errors or standard deviations. We considered differences suggestive at $\alpha \leq 0.10$ and statistically significant at $\alpha \leq 0.05$.

\section{RESULTS}

\section{Landscape Scale}

Point-transect surveys indicated that Micronesian kingfishers occurred throughout the island of Pohnpei and on all transect routes. We detected 480 Micronesian kingfishers that occurred at $79 \%$ of the 184 survey stations. The mean detection frequency was 15.65 birds per hour for all surveys, 8.05 birds per hour in high elevations (above $400 \mathrm{~m}$ ), and 17.82 birds per hour in low elevations. Compared to transects where we did not detect Micronesian kingfishers, point-transects with kingfishers had a mean of 1.9 ( $\mathrm{SE}=$ $0.7)$ ha more wet forest $\left(F_{1,182}=7.38, P=0.007\right), 6.1$ ( $\mathrm{SE}=$ 1.2) ha less upland forest $\left(F_{1,182}=26.06, P<0.001\right)$, and $2.3(\mathrm{SE}=0.7)$ ha more grass-urban habitat $\left(F_{1,182}=10.25\right.$, $P=0.002)$ within $250 \mathrm{~m}$ of point-transect stations.

The model-ranking process also indicated a strong relationship between vegetative cover and the number of kingfishers detected at each point-transect station. All 5 vegetation cover variables occurred in the top 12 models, which encompassed $>90 \%$ of the overall $w_{i}$ (Table 1 ). Parameter inclusion and $w_{i}$ estimates from the set of 12 indicated that the order of variable influence was agricultural forest $<$ upland forest $<$ grass-urban $<$ disturbed vegetation $<$ wet forest (Burnham and Anderson 2002; cumulative $w_{j} 0.76,0.75,0.58,0.57,0.53$, respectively). Model-averaged unconditional parameter estimates indicated a positive relationship between the number of bird detections at each station and wet forest (estimated 133\% change in detections for each 10 ha of wet forest habitat added, 95\% CI $=90-195 \%)$. There was a similar relationship between bird detections and grass-urban cover ( $137 \%$ change in bird detections for each 10 ha of grassurban habitat added, 95\% CI $=97-195 \%$ ). To the contrary, the remaining 3 habitats were negatively associated with the number of bird detections. Specifically, parameters suggested that kingfisher detections would drop 
Table 2. Vegetative coverages (ha) observed in the $95 \%$ kernel-density home ranges of Micronesian kingfishers on the island of Pohnpei, Federated States of Micronesia, 1999, 2000, and 2002.

\begin{tabular}{|c|c|c|c|c|c|c|c|c|c|c|c|}
\hline & \multirow{2}{*}{$\frac{\text { Birds }}{n}$} & \multicolumn{2}{|c|}{ Short grass } & \multicolumn{2}{|c|}{ Tall grass } & \multicolumn{2}{|c|}{$\begin{array}{c}\text { Early } \\
\text { succession forest }\end{array}$} & \multicolumn{2}{|c|}{$\begin{array}{c}\text { Late- } \\
\text { succession forest }\end{array}$} & \multicolumn{2}{|c|}{ Edge } \\
\hline & & $\bar{x}$ & SD & $\bar{x}$ & SD & $\bar{x}$ & SD & $\bar{x}$ & SD & $\bar{x}$ & SD \\
\hline \multicolumn{12}{|l|}{ Dominant } \\
\hline Pair & 18 & 0.75 & 0.23 & 1.48 & 0.30 & 0.67 & 0.09 & 2.24 & 0.32 & 2.76 & 0.48 \\
\hline Cooperative & 16 & 0.96 & 0.27 & 1.96 & 0.44 & 1.08 & 0.12 & 2.94 & 0.30 & 4.25 & 0.54 \\
\hline \multicolumn{12}{|l|}{ Helper } \\
\hline Cooperative & 11 & 0.80 & 0.28 & 3.46 & 1.30 & 1.19 & 0.28 & 3.35 & 0.85 & 6.72 & 2.50 \\
\hline \multicolumn{12}{|l|}{ Juv } \\
\hline Pair & 9 & 0.30 & 0.24 & 1.02 & 0.32 & 0.56 & 0.06 & 2.08 & 0.32 & 2.07 & 0.38 \\
\hline Cooperative & 7 & 0.54 & 0.43 & 1.27 & 0.33 & 0.51 & 0.13 & 1.55 & 0.16 & 1.95 & 0.53 \\
\hline
\end{tabular}

$35 \%(95 \%$ CI $=6-56 \%)$ for each added 10 ha of agricultural forest, $41 \%(95 \% \mathrm{CI}=11-62 \%)$ for each 10 added ha of upland forest, and $6 \%(95 \% \mathrm{CI}=-31-41 \%)$ for each added 10 ha of secondary vegetation.

\section{Home-Range Scale}

We estimated the home ranges of 61 Micronesian kingfishers using a mean of 61 ( $\mathrm{SD}=20$, range $=13-97$ ) observations. The study population included 34 dominants on both pair (8 M:10 F) and cooperative (9 M:7 F) territories, 11 helpers ( $8 \mathrm{M}: 3 \mathrm{~F})$, and 16 hatch-year birds from pair-held (3 M:6 F) and cooperative (3 M:4 F) territories.

Habitat use.-The home ranges of Pohnpei Micronesian kingfishers within the study areas encompassed nearly all forested areas and forest edges. The home ranges of birds from neighboring territories abutted in forests and along forest edges although gaps of short and tall grasses occurred between the home ranges of birds on some neighboring territories. Home ranges were also elongated to avoid open grassy areas and they often included extensions encompassing particular habitat features such as trees.

Mean home-range size was $5.95(\mathrm{SE}=0.53)$ ha; 5.54 $(\mathrm{SE}=0.34)$ ha with a single outlier removed. Within $95 \%$ home-range contours, birds used a mean of $0.72(\mathrm{SE}=0.12)$ ha of short grass, $1.87(\mathrm{SE}=0.29)$ ha of tall grass, $0.84(\mathrm{SE}$ $=0.07)$ ha of early succession forest, and $2.52(\mathrm{SE}=0.21)$ ha of late-succession forest (Table 2). Additionally, kingfisher home ranges encompassed a mean of $4.7(\mathrm{SE}=0.6) \mathrm{km}$ of forest edge. Within each territory, habitat use differed among social classes. Bonferroni-adjusted results indicated that when compared to dominants and helpers, juveniles used less short grass $\left(t_{44}=3.39, P=0.005 ; t_{44}=3.25, P=\right.$ $0.007)$, less tall grass $\left(t_{49}=3.14, P=0.009 ; t_{47}=3.07, P=\right.$ $0.011)$, less early succession forest $\left(t_{51}=3.20, P=0.002\right.$; $\left.t_{48}=3.34, P=0.005\right)$, less late-succession forest $\left(t_{52}=2.79\right.$, $\left.P=0.022 ; t_{48}=2.76, P=0.024\right)$, and less forest edge $\left(t_{51}=\right.$ $\left.3.21, P=0.007 ; t_{48}=3.62, P=0.002\right)$. Dominants and helpers did not differ in their use of any of the 5 habitats (Table 2). Habitat use differed among sexes. For breeders, there was suggestive evidence that males used more shortgrass area $\left(t_{16}=-1.87, P=0.079\right)$ and early succession forest $\left(t_{24}=-1.81, P=0.083\right)$ than females. Similarly, among helpers there was suggestive evidence that males used more short grass $\left(t_{2.01}=-4.18 P=0.052\right)$, tall grass $\left(t_{2.02}=\right.$ $-7.42 P=0.017)$, and early succession forest $\left(t_{2.37}=-2.76\right.$ $P=0.091)$ than females. We identified no differences among any of the other metrics or between male and female juveniles $(P>0.10$ for all).

We also compared habitat use between cooperative and pair-held territories (Table 2). Compared to dominants breeding as pairs, those on cooperative territories used more early succession forest $\left(t_{32}=-2.81, P=0.008\right)$. There was also suggestive evidence that dominant home ranges on cooperative territories encompassed more edge habitat $\left(t_{32}=\right.$ $-2.06, P=0.050)$ and late-succession forest $\left(t_{32}=-1.83\right.$, $P=0.076$ ). Dominants on cooperative and pair territories did not differ in their use of short- or tall-grass habitats and we detected no habitat differences between juveniles on pair or cooperative territories $(P>0.10$ for all).

Habitat selection.-Micronesian kingfishers selectively used and avoided particular habitats (Table 3). Cover-type proportions in kingfisher home ranges differed from those in randomly placed polygons for all birds considered together $\left(\chi_{3}^{2}=140, P<0.001\right)$, breeders alone $\left(\chi_{3}^{2}=36, P<\right.$ $0.001)$, helpers alone $\left(\chi_{3}^{2}=54, P<0.001\right)$, and juveniles

Table 3. Habitat selection in Micronesian kingfishers on Pohnpei Island, Federated States of Micronesia, as determined by comparing habitat proportions in observed home ranges with those in nearby randomly located polygons of similar size and shape. Home ranges were based on radiotelemetry conducted between 1999 and 2004. We used the method of Neu et al. (1974) to make comparisons and Bonferroni simultaneous confidence intervals to assess significance.

\begin{tabular}{lcccc}
\hline Social class & $\begin{array}{c}\text { Short } \\
\text { grass }^{\text {a }}\end{array}$ & $\begin{array}{c}\text { Tall } \\
\text { grass }^{\mathbf{a}}\end{array}$ & $\begin{array}{c}\text { Early } \\
\text { succession }_{\text {forest }}{ }^{\mathbf{a}}\end{array}$ & $\begin{array}{c}\text { Late- } \\
\text { succession }^{\text {forest }}{ }^{\mathbf{a}}\end{array}$ \\
\hline Juv & $\mathrm{A}$ & $\mathrm{A}$ & 0 & $\mathrm{~S}$ \\
Helpers & $\mathrm{A}$ & $\mathrm{A}$ & 0 & $\mathrm{~S}$ \\
Dominants & $\mathrm{A}$ & 0 & 0 & $\mathrm{~S}$ \\
All kingfishers & $\mathrm{A}$ & $\mathrm{A}$ & 0 & $\mathrm{~S}$ \\
\hline
\end{tabular}

"An "S" represents significantly more of the habitat in observed home ranges than simulated polygons (i.e., or selection for the habitat). An " $\mathrm{A}$ " represents significantly less habitat in observed home ranges (i.e., avoidance). A zero (0) denotes habitat use in proportions to availability. 
alone $\left(\chi_{3}^{2}=84, P<0.001\right)$. Results further indicated that Micronesian kingfisher home ranges included 3.4\% less short-grass area $(95 \% \mathrm{CI}=-4.4$ to $-2.3 \%, P<0.001)$, $4.0 \%$ less tall grass $(95 \% \mathrm{CI}=-5.4$ to $-2.5 \%, P<0.001)$, and $6.4 \%$ more late-succession forest $(95 \% \mathrm{CI}=4.8-8.0 \%$, $P<0.001)$ than polygons that we randomly placed within the immediate vicinity of each home range. The same general pattern held when we broke down selection by social class (Table 3). We found no difference in the length of edge habitat in Micronesian kingfisher home ranges and nearby simulated polygons $\left(t\right.$-test; $\left.t_{59}=1.93, P>0.05\right)$.

\section{DISCUSSION}

Our results suggested that although Micronesian kingfishers occurred throughout Pohnpei, temporal population fluctuations, vegetative cover type, and habitat composition have the potential to affect localized population density at both the landscape and home-range scales. When compared to previous surveys, our results indicate that Pohnpei Micronesian kingfisher densities may change dramatically with time. Point-transect encounter rates reported in 1983 were 13.3 detections per hour above $400 \mathrm{~m}$ in elevation and 21.0 detections per hour below (Engbring et al. 1990). In 1994, 6.2 kingfishers were detected during each survey hour above $400 \mathrm{~m}$ and 5.6 were reported below (Buden 2000). Although detection rates have increased since 1994 , our results $(8.1 / \mathrm{hr}$ and $17.8 / \mathrm{hr}$, respectively) indicate a decline of $40 \%$ and $15 \%$, respectively, since 1983 .

At the landscape scale, point-transect results indicated that Micronesian kingfishers were positively associated with the wet forest and grassland vegetation structures that are typical to Pohnpei's lowlands, and that the birds were detected less frequently in the vegetation cover types that are characteristic of Pohnpei's mountainous areas (Fig. 1). In this respect, our results were similar to previous findings from Pohnpei that showed higher Micronesian kingfisher densities at sea level and decreased densities at upper elevations (Engbring et al. 1990, Buden 2000). Conversely, surveys on the island of Palau (Engbring 1992) indicated that Micronesian kingfishers were more abundant in upland forests than in lowlands and mangrove forests. Unlike Pohnpei, however, low elevations on Palau are also inhabited by a larger congener ( $T$. chloris teraokai), which may aggressively exclude Micronesian kingfishers from prime lowland habitats.

Micronesian kingfishers also selected for areas with greater forest vegetation development at the home-range scale. Kingfishers excavate nest cavities from the arboreal nests of termites (Nasutitermes spp.), or termitaria (Marshall 1989, Kesler and Haig 2005a), and they select for larger and higher termitaria and termitaria in areas with greater canopy cover (Kesler and Haig 2005b). Greater canopy cover, higher trees, and older termitaria are more likely to occur in older sections of forest and sections with greater vegetation development. Thus, Micronesian kingfishers may have selected for late-succession forests at both the landscape and home-range scale because they contained termitaria that were suitable for nesting. Home-range results further illustrated that Micronesian kingfishers used grassy areas in lower proportions than random availability predicted. Researchers have previously referred to the disproportionately low use of a particular habitat as avoidance (e.g., Meyer et al. 2005). However, the term does not adequately describe the pattern that we observed in the Micronesian kingfishers, because the birds did not exclude grassy areas from home ranges altogether. Rather, radiomarked birds commonly used grassy open areas, where they foraged from perches along forest edges and duet- or trio-called in opposition to neighboring birds during morning and evening hours. The kingfishers then retreated to the cooler shady forested areas during warmer portions of the day. We, therefore, suggest that Micronesian kingfishers selected for a combination of both grassy and forested areas, although the availability of the 2 habitat types may have differed on the landscape.

Identification of limited resources that underlie delayed dispersal has the potential to profoundly influence our understanding of cooperative behaviors and the conservation management of endangered species. Previous investigations of cooperatively breeding species have identified 2 primary ways that resources can affect dispersal behaviors. Potential dispersers may delay either because resources are so restricted in the environment that there are few dispersal opportunities (ecological constraints hypothesis; Emlen 1982) or because resources on natal areas are of sufficiently high quality that reproduction lost while waiting to inherit them will eventually be offset with long-term fitness gains (benefits of philopatry hypothesis; Stacey and Ligon 1991). Our results indicated that birds selected for forested areas and that forests on the study areas were saturated with territories. This suggests that potential dispersers were constrained by limitations in extraterritorial availability of forest resources. However, the home ranges of Micronesian kingfishers in cooperative groups included more forested areas than birds in pairs so our results also indicated that potential dispersers might be delaying dispersal on higher quality territories with more forest resources. Therefore, our results provided supporting evidence for both premier hypotheses about the evolution of delayed dispersal because they indicated that there were limitations in extraterritorial forest habitats and that there were superior forest resources on cooperative territories.

\section{MANAGEMENT IMPLICATIONS}

Our results underscore the vital importance of considering forest resources when managing wild populations of Micronesian kingfishers. On Pohnpei, native forests have declined by $>70 \%$ during the last 3 decades (Newsome et al. 2003) and similar habitat declines characterize Palau. Although Micronesian kingfishers' tolerance for open areas may render them somewhat resilient to native vegetation conversion, our results indicated that disturbed and secondary vegetative cover were associated with lower detection frequencies. Thus, the continued conversion from native forests to introduced and agricultural vegetation types 
may result in reduced Micronesian kingfisher populations. Coordinated landscape planning has the potential to conserve native vegetation and limit the impacts of anthropogenic development. Current efforts for forest preservation on Pohnpei include a large protected forest reserve (Dahl and Raynor 1996). Initiation of forest protection efforts on Guam and Palau may similarly benefit wild kingfisher populations. Guam Micronesian kingfishers are extinct in the wild, but plans are currently underway for reintroductions to their native range (United States Fish and Wildlife Service 2004). Our results indicated that a landscape with patchy combinations of late-succession forest and open vegetation might provide habitat resources necessary for the birds. Thus, conservation practitioners planning Micronesian kingfisher reintroductions on Guam should consider areas of Andersen Air Force Base in northern Guam and Navy Base Guam in the central region of the island because they contain some of the last vestiges of the island's native forests.

\section{ACKNOWLEDGMENTS}

We are indebted to all those who have provided financial and technical support to the project. The United States Geological Survey Forest and Rangeland Ecosystem Science Center, United States Fish and Wildlife Service, Conservation Endowment Fund of the American Zoo and Aquarium Association, National Geographic Society, Disney's Animal Kingdom, St. Louis Zoo Field Research for Conservation Fund, Brookfield Zoo, Friends of the National Zoo, the Micronesian Kingfisher Species Survival Fund, and the Milwaukee County Zoo provided financial backing for the project. B. Dugger, L. Houck, L. Kesler, O. Taft, and J. Walters provided valuable comments on study design and the manuscript development. D. Buden and B. Raynor provided advice on Pohnpei. We also extend thanks to the government of the Federated States of Micronesia, $\mathrm{H}$. Anson, R. Mauricio, the landowners in Pohnpei, and everyone in the Haig Lab. M. Boris, C. Cantero, J. Santos, and P. Sanzenbacher also made contributions as field assistants and cultural guides.

\section{LITERATURE CITED}

Avery, T. E., and G. L. Berlin. 1992. Fundamentals of remote sensing and air photo interpretation. MacMillan, New York, New York, USA.

Baker, R. H. 1951. The avifauna of Micronesia, its origin, evolution, and distribution. University of Kansas Museum of Natural History Publication, Lawrence, USA.

Baltz, A. P. 1998. The assessment of reproductive potential in Micronesian kingfisher pairs. Zoo Biology 17:425-432.

Brown, J. L. 1987. Helping and communal breeding in birds: ecology and evolution. Princeton University Press, New Jersey, USA.

Buckland, S. T., D. R. Anderson, K. P. Burnham, and J. L. Laake. 1993. Distance sampling: estimating abundance of biological populations. 1999, Reprint. Research Unit for Wildlife Population Assessment, University of St. Andrews, Scotland.

Buden, D. W. 2000. A comparison of 1983 and 1994 bird surveys of Pohnpei, Federated States of Micronesia. Wilson Bulletin 112:403-410.

Burnham, K. P., and D. R. Anderson. 2002. Model selection and multimodel inference: a practical information-theoretic approach. Springer, New York, New York, USA.
Carmen, W. J. 2004. Non-cooperative breeding in the California Scrub-Jay. Studies in Avian Biology 28:1-100.

Clarke, M. F., and G. F. Fitz-Gerald. 1994. Spatial organization of the cooperatively breeding bell miner Manorina melanophrys. Emu 94: 96-105.

Conner, R. N., D. C. Rudolph, and J. R. Walters. 2001. The red-cockaded woodpecker. University of Texas Press, Austin, USA.

Copeyon, C. K., J. R. Walters, and J. H. Carter, III. 1991. Introduction of red-cockaded woodpecker group formation by artificial cavity construction. Journal of Wildlife Management 1991:549-556.

Dahl, C., and B. Raynor. 1996. Watershed planning and management: Pohnpei, Federated States of Micronesia. Asia Pacific Viewpoint 37: 235-251.

Emlen, S. T. 1982. The evolution of helping. I. An ecological constraints model. American Naturalist 119:29-39.

Engbring, J. 1992. A 1991 survey of the forest birds of the Republic of Palau. U.S. Fish and Wildlife Service, Honolulu, Hawaii, USA.

Engbring, J., and F. L. Ramsey. 1984. Distribution and abundance of the forest birds of Guan: results of a 1981 survey. U.S. Fish and Wildlife Service, Washington, D.C., USA.

Engbring, J., F. L. Ramsey, and V. Wildman. 1990. Micronesian forest bird surveys, the Federated States: Pohnpei, Kosrae, Chuuk, and Yap. Report to the U.S. Fish and Wildlife Service. U.S. Fish and Wildlife Service, Honolulu, Hawaii, USA.

Fry, C. H., K. Fry, and A. Harris. 1992. Kingfishers, bee-eaters, \& rollers. Princeton University Press, Princeton, New Jersey, USA.

Haig, S. M., and J. D. Ballou. 1995. Genetic diversity in two avian species formerly endemic to Guam. Auk 112:445-455.

Haig, S. M., J. D. Ballou, and N. J. Casna. 1995. Genetic identification of kin in Micronesian kingfishers. Journal of Heredity 86:423-431.

Hale, A. M., D. A. Williams, and K. N. Rabenold. 2003. Territoriality and neighbor assessment in brown jays (Cyanocorax morio) in Costa Rica. Auk 120:446-456.

Haydock, J., and W. D. Koenig. 2002. Reproductive skew in the polygynandrous acorn woodpecker. Proceedings of the National Academy of Sciences of the United States of America 99:7178-7183.

Heppell, S. H., J. R. Walters, and L. R. Crowder. 1994. Evaluating management alternatives for red-cockaded woodpeckers: a modeling approach. Journal of Wildlife Management 58:479-487.

Jenkins, J. M. 1983. The native forest birds of Guam. American Ornithologists' Union, Ornithological Monographs 31, Washington, D.C., USA.

Johnson, D. H. 1980. The comparison of usage and availability measurements for evaluating resource preference. Ecology 61:65-71.

Katnik, D. D., and R. B. Wielgus. 2005. Landscape proportions versus Monte Carlo simulated home ranges for estimating habitat availability. Journal of Wildlife Management 69:20-32.

Kesler, D. C. 2002. Nest site selection in cooperatively breeding Pohnpei Micronesian Kingfishers (Halcyon cinnamomina reichenbachii): does nestsite abundance limit reproductive opportunities? Thesis, Oregon State University, Corvallis, USA.

Kesler, D. C. 2006. Population demography, resource use, and movement in cooperatively breeding Micronesian Kingfishers. Dissertation, Oregon State University, Corvallis, USA.

Kesler, D. C., and S. M. Haig. 2004. Thermal characteristics of wild and captive Micronesian kingfisher nesting habitats. Zoo Biology 23: 301-308

Kesler, D. C., and S. M. Haig. 2005a. Microclimate and nest site selection in Micronesian kingfishers. Pacific Science 59:499-508.

Kesler, D. C., and S. M. Haig. 2005b. Selection of arboreal termitaria for nesting by cooperatively breeding Pohnpei Micronesian Kingfishers. Ibis 147:188-196.

Kesler, D. C., and S. M. Haig. 2007a. Conservation biology for suites of species: population demography for the Todiramphus Kingfishers. Biological Conservation 136:520-530.

Kesler, D. C., and S. M. Haig. 2007b. Territoriality, prospecting, and dispersal in cooperatively breeding Micronesian Kingfishers. Auk 124:in press.

Kesler, D. C., I. F. Lopes, and S. M. Haig. 2006. Sex determination in the Pohnpei Micronesian kingfisher using morphological and molecular genetic techniques. Journal of Field Ornithology 77:229-232.

Koenig, W. D., and J. L. Dickinson, editors. 2004. Ecology and evolution 
of cooperative breeding in birds. Cambridge University Press, New York, New York, USA.

Koenig, W. D., P. N. Hooge, M. T. Stanback, and J. Haydock. 2000. Natal dispersal in the cooperatively breeding acorn woodpecker. Condor 102: 492-502.

Koenig, W. D., D. Van Vuren, and P. N. Hooge. 1996. Detectability, philopatry, and the distribution of dispersal distances in vertebrates. Trends in Ecology and Evolution 11:514-517.

Komdeur, J. 1991. Influence of territory quality and habitat saturation on dispersal options in the Seychelles warbler: an experimental test of the habitat saturation hypothesis for cooperative breeding. Acta XX Congressus Internationalis Ornithologici Vol III:1325-1332.

Komdeur, J. 1992. Importance of habitat saturation and territory quality for evolution of cooperative breeding in Seychelles warbler. Nature 358: 493-494.

Komdeur, J. 1994. Experimental evidence for helping and hindering by previous offspring in the cooperative-breeding Seychelles warbler Acrocephalus sechellensis. Behavioral Ecology and Sociobiology 34:175-186.

Komdeur, J, and M. D. Pels. 2005. Rescue of the Seychelles warbler on Cousin Island, Seychelles: the role of habitat restoration. Biological Conservation 124:15-26.

Langen, T. A., and S. L. Vehrencamp. 1998. Ecological factors affecting group and territory size in white-throated magpie-jays. Auk 115: 327-339.

Leban, F. 1999. Resource selection for Windows Version 1.0. University of Idaho, Moscow, USA.

Marshall, J. T., Jr. 1949. The endemic avifauna of Saipan, Tinian, Guam, and Palau. Condor 51:200-221.

Marshall, S. D. 1989. Nest sites of the Micronesian kingfisher on Guam. Wilson Bulletin 101:472-477.

McClean, S. A., M. A. Rumble, R. M. King, and W. Baker. 1998. Evaluation of resource selection methods with different definitions of availability. Journal of Wildlife Management 62:793-801.

Meyer, M. D., D. A. Kelt, and M. P. North. 2005. Nest trees of northern flying squirrels in the Sierra Nevada. Journal of Mammalogy 86:275-280.
Mueller-Dombois, D., and F. R. Fosberg. 1998. Vegetation of the tropical Pacific islands. Springer, New York, New York, USA.

Neu, C. W., C. R. Byers, and J. M. Peek. 1974. A technique for analysis of utilization-availability data. Journal of Wildlife Management 38: $541-545$

Newsome, P. F., M. J. Page, and H. A. Heke. 2003. Vegetation map of Pohnpei 2002, Federated States of Micronesia. Landcare Research New Zealand, unpublished contract report LC0203/079, Palmerston North, New Zealand.

Porter, J. H., and J. L. Dooley. 1993. Animal dispersal patterns: a reassessment of simple mathematical models. Ecology 73:2436-3443.

Ramsey, F. L., and D. W. Schafer. 1997. The statistical sleuth: a course in methods of data analysis. Duxbury Press, Belmont, United Kingdom.

Rappole, J. H., and A. R. Tipton. 1991. New harness design for attachment of radio transmitters to small passerines. Journal of Field Ornithology 62: 335-337.

Sanchez, C., and S. Murray. 2005. Diagnosis and successful treatment of a presumptive case of aspergillosis in a Micronesian kingfisher (Halcyon cinnamomina cinnamomina). Avian Diseases 49:309-312.

Stacey, P. B., and J. D. Ligon. 1991. The benefits-of-philopatry hypothesis for the evolution of cooperative breeding: variation in territory quality and group size effects. American Naturalist 138:831-846.

Stophlet, J. J. 1946. Birds of Guam. Auk 63:534-541.

United States Fish and Wildlife Service. 2004. Draft revised recovery plan for the sihek or Guam Micronesian kingfisher (Halcyon cinnamomina cinnamomina). U.S. Fish and Wildlife Service, Portland, USA.

Walters, J. R., C. K. Copeyon, and J. H. Carter, III. 1992. Test of the ecological basis of cooperative breeding in Red-cockaded Woodpeckers. Auk 109:90-97.

White, G. C., and R. A. Garrott. 1990. Analysis of wildlife radiotracking data. Academic Press, San Diego, California, USA.

Associate Editor: Kuenzi. 